\title{
Design and Fabrication of Tiger Nut Juice Extractor
}

\author{
${ }^{1 *}$ RAJI, NA; ${ }^{2}$ ADEDEJI, KA; ${ }^{2}$ OLALEYE, JO; ${ }^{2}$ ADELE, FA \\ ${ }^{I}$ Mechanical Engineering Department, Elizade University Ilara-Mokin, Nigeria \\ ${ }^{2}$ Mechanical Engineering Department, Lagos State University, Ojo, Nigeria \\ *Correspondence Author Email: nurudeen.raji@elizadeuniversity.edu.ng
}

\begin{abstract}
Tiger nut tuber is rich in energy content, nutrients and minerals. The tuber which is usually stored dried could be processed by rehydration to improve the extraction of the milk content. The machine is developed to extract the milk contents of the crop for purpose of consumption and other usages. The design is made of the feeding segment, the extraction segment, power segment and the frame support which serves as the machine subassemblies. The design of the screw and drive mechanism is emphasize to ensure efficient performance of the machine. The machine is driven by a belt drive system powered by a $2 \mathrm{hp}$. electric motor operating at a speed of $1100 \mathrm{rpm}$. The efficiency of the machine is within the range of 53-55\% for a power requirement of $1.514 \mathrm{~kW}$. The machine is found suitable for small scale operation.
\end{abstract}

\section{DOI: https://dx.doi.org/10.4314/jasem.v23i3.29}

Copyright: Copyright (0) 2019 Raji et al. This is an open access article distributed under the Creative Commons Attribution License (CCL), which permits unrestricted use, distribution, and reproduction in any medium, provided the original work is properly cited.

Dates: Received: 17 November 2018; Revised: 19 January 2019; Accepted 22 January 2019

Keywords: extractor, tiger nut, auger screw, hopper

Tiger nut is a weed plant largely found in Tropical and Mediterranean regions. It is a tuber with high health benefits and nutritive value (Oguwike et al., 2017). It is a family of sedge crops rich in energy content (starch, fat, sugar, and protein), nutrients like vitamin $\mathrm{E}$ and $\mathrm{C}$ and minerals like magnesium, phosphorus, iron, calcium, carbohydrate, protein including unsaturated fats and some enzymes which aid digestion (Sanchez-Zapata et al., 2012; Ogbonna et al., 2013). Tiger nut loses a sizeable amount of its water content during storage and this causes the starch content of the tubers to reduce but can be rehydrated with water without losing its crisp texture. The juice extracted from the nut is a nonalcoholic beverage of milky appearance. Tiger nut is also said to high in oil content producing high quality of oil of about $25.5 \%$ of its total content (Adejuyitan, 2011). The tiger nut milk contains more iron, magnesium and carbohydrate than cow milk as reported in Chevalier, (1996). It also has the advantage of not containing sodium and cholesterol which makes it ideal for people who are hypertensive (Ogbonna et al., 2013). The antioxidant activity of the methanolic extract of the tiger nut and the total phenolic content was determined as presented in Ogunlade et al., (2015). The results revealed that tiger nut contains substantial amount of protein and carbohydrate and has significantly high contents of $\mathrm{Na}, \mathrm{K}$ and $\mathrm{Ca}$ which suggest that the nut is good for formulating diet for hypertensive patients. The tiger nut flour is considered as a good additive for the bakery industry because of its natural sugar content and can also be used as flavoring agent for ice cream (Bamishaiye and Bamishaiye, 2011). The flour had been found to be a good substitute for cereal grains and bakery products and has been found to be useful in the cosmetic industry for the production of soap and oil (Al-Shaikh et al., 2013). Its fiber content could cut down the rate of obesity aiding complete digestion thus prevent slow metabolic rate in humans (Owusu and Owusu, 2016). The aqueous extract of the tiger nut was found to have beneficial effect on the sperm parameters of human (Ekaluo et al., 2015). The concern for the mechanical processing of the tiger nut cannot be overemphasized as a result of its important usages. The mechanical processing of tiger nut includes washing and hydration, juice extraction, mixing of the juice with required flavor and sugar and storage. This study is concerned with the development of equipment for the tiger nut juice extraction stage. Juice extractor machines are used to extract liquid contents of crops especially for juice. A major importance in extraction of crop juice and preservation is the intent to avoid post-harvest wastage often experience especially in developing countries where the juice crops are in abundance. Developing the juice extractor machine had been the focus of research for machine design engineers over the years and several attempts had been made in developing the economic manually operated design as well as the motorized concept. 
A manually operated machine for extraction of juice is well described in Ogunsina and Lucas, (2008). The tiger nuts were milled to reduce the size of the particles in order to facilitate the milk extraction process. Mechanical pressing has been established as the most common extraction method and several attempts had been reported for the development of mechanical press for extraction of juice from fruits, tubers and grains and in recent time designers had focused on improving the developing of the machine which has encouraged the emergence of different modification (Eyeowa et al, 2017; Odewole et al., 2018). The focus of most of the design is to optimize the cost of processing and maintenance of the equipment. Most of the design emphasized on the use of local materials. However the speed of operation of such machines depends largely on the ability of the operator to exert continuous and steady effort on the lever.

The attempt to improve juice extracting productivity on a large scale had encouraged the development of the motorized extractors; fabrication and performance evaluation of pineapple juice extractor (Adebayo et al., 2013), Orange juice extractor (Adanu et al., 2015), sugarcane juice extractor (Adewole et al., 2015), multipurpose juice extractor (Aviara et al., 2015; Mercado et al., 2016; Omoregie et al., 2018). The search for optimum milk extraction process for the exploitation of the benefits of such underutilized crop like the tiger nut cannot be over emphasized. This paper attempts to develop a suitable cost effective machine that could be used for the extraction of the milk content of the tiger nut crop.

\section{MATERIALS AND METHODS}

The machine consists of four segments which are; the feeding segment, the power segment, the outlet segment, and the frame. The feeding segment consists of the hopper, the outlet or extraction segment consist of the auger screw shaft, the perforated barrel, the power segment consist of the shaft, the belt, the pulleys, and the motor. The frame serves as the support of the machine where the other entire segment will be mounted. The design concept focus on the possibilities of achieving high extraction efficiency of juice, availability of local materials, ease of operation, low cost extraction and simplicity in operation and maintenance of the machine. The effectiveness of the screw type extraction is evident in Abou-Arab et al., (2017). The material consideration for the design is as given in Table 1 and Table 2.

Design Analysis: The design analysis for the various features are as discussed below. The machine as designed is shown in Figure 1

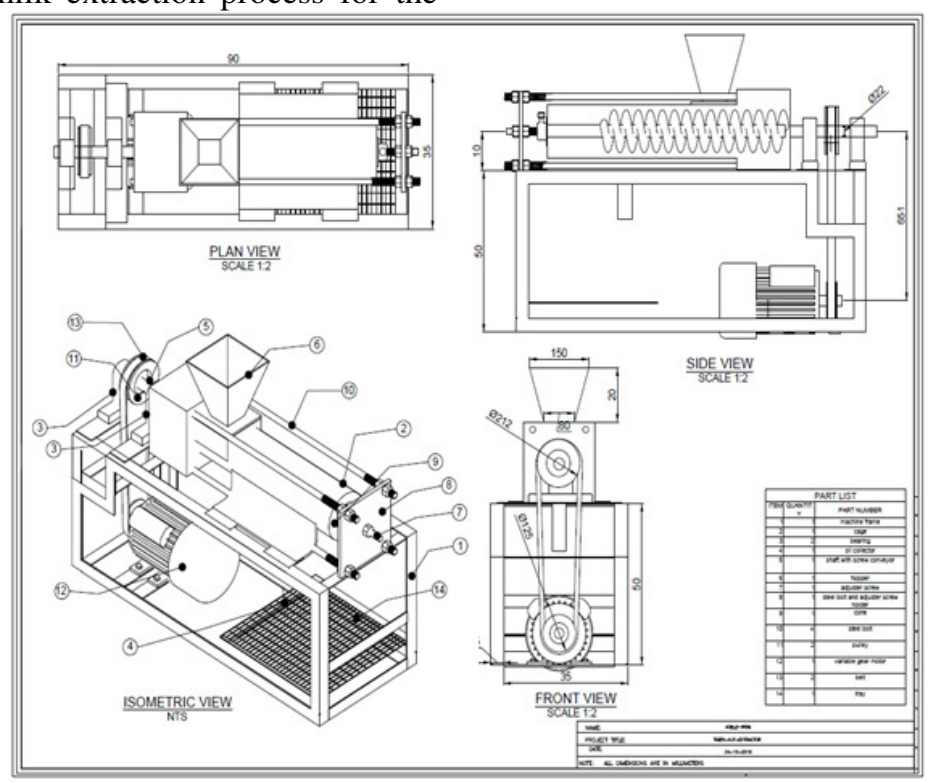

Fig 1 Tiger nut juice extractor

The Hopper: The machine hopper made of mild steel plate is developed as a frustum whose volume is obtained as defined in equation (1) to contain $\leq 3 \mathrm{~kg}$ of the tiger nuts.

$$
V=\frac{h}{3}\left[B_{1}+B_{2}+\sqrt{B_{1} \times B_{2}}\right]
$$

Where $V$ the volume of the frustum is, $h$ is the height of the frustum, $B_{1}$ is the area of the top square, and $B_{2}$ is the area of the bottom square.

The Belt drive system: The machine is considered driven by a belt drive system. The design of the drive 
mechanism is as discuss in Raji et al., 2016. The power output of the belt drive is obtained as expressed in equation (2).

$$
P=T_{1}\left(1-e^{\frac{\mu}{\sin \beta} \theta_{i}}\right) v_{b}(1-\varepsilon)
$$

Where $\varepsilon$ is the belt slippage factor which usually lies within the range $0.005 \leq \varepsilon \leq 0.03, \mathrm{v}_{\mathrm{b}}$ is the belt speed and $\mathrm{T}_{1}$ is the transmitting tension.

The constraint sets considered for maximum transmission of power for the design are as obtained in equations (3)-(7). The maximum power transmission could be obtained limiting the initial tension in the belt as expressed in equation (3).

$g_{1}=T_{o}-3 \rho v_{b}^{2}=0$

The belt pitch length for the drive is obtained as expressed in equation (4).

$L_{p}=2 C+\pi\left(R_{A}+R_{B}\right)+\left(R_{A}-R_{B}\right)^{2} / C$

Where the pulley center to center distance is obtained from equation (5).

$C=0.25\left\{\left[L_{p}-\pi\left(R_{A}+R_{B}\right)\right]+\sqrt{\left[L_{p}-\pi\left(R_{A}+R_{B}\right)\right]^{2}-8\left(R_{A}-R_{B}\right)^{2}}\right\}$

The center to center distance is limited by the following constraint;

Table 1 Material selection for tiger nut juice extractor

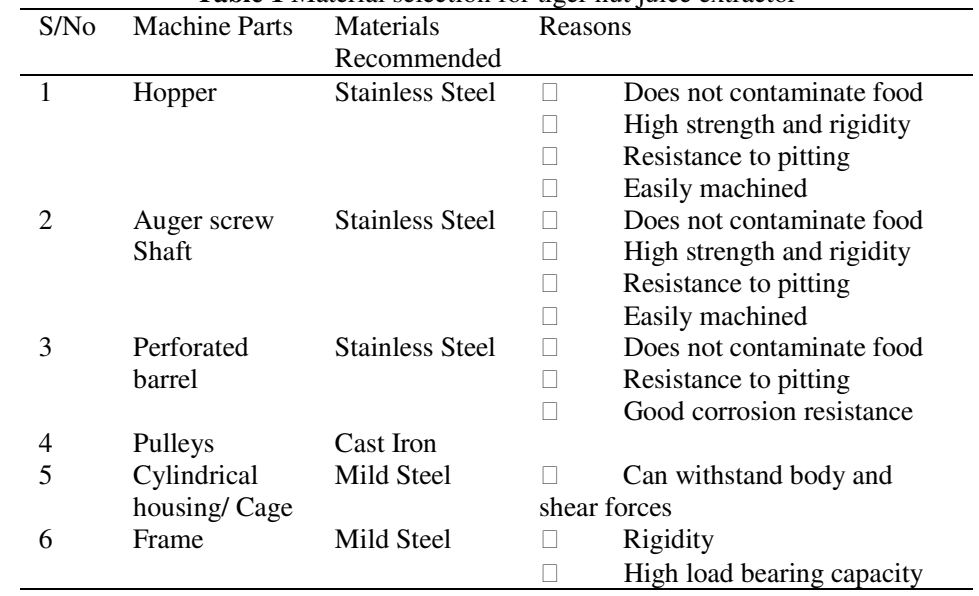

Table 2 Properties of steel materials.

\begin{tabular}{llllll}
\hline Material & $\begin{array}{l}\text { Modulus of } \\
\text { Elasticity } \\
\text { (Moa) }\end{array}$ & $\begin{array}{l}\text { Poisson's } \\
\text { Ratio }\end{array}$ & $\begin{array}{l}\text { Density } \\
(\mathrm{kg} / \mathrm{m} 3)\end{array}$ & $\begin{array}{l}\text { Yield Strength } \\
(\mathrm{MPa})\end{array}$ & $\begin{array}{l}\text { Tensile } \\
\text { Strength (MPa) }\end{array}$ \\
\hline $\begin{array}{l}\text { Mild S teel } \\
\text { S tainless }\end{array}$ & $2.00 \mathrm{E}+05$ & 0.33 & 7850 & 230 & 580 \\
S teel & $2.00 \mathrm{E}+05$ & 0.33 & 7850 & 250 & 450 \\
\hline
\end{tabular}

$g_{2}(R)=\frac{R_{A}-R_{B}}{R_{A}+R_{B}} \operatorname{Csc} \phi-6 \leq 0$

$\phi=\operatorname{Sin}^{-1}\left(\frac{R_{A}-R_{B}}{C}\right)$

The electric motor specification for the machine could therefore be obtained as determined from equation (2). Where $R_{A}$ and $R_{B}$ are the output and input pulley radii respectively, $\mu, \beta, \theta_{\text {I }}$ are the pulley-belt contact friction coefficient, pulley groove half angle and pulley angle of lap on the input pulley.

Screw auger design: The auger screw is responsible for conveying the load and squeezing against the machine end plate for the extraction process. The shaft material considered for the design is the stainless steel. The screw structure adopted is shown in Figure 2. A hollow shaft is designed for the operation considering the cost benefit having chosen stainless steel. The layout for the auger screw is as shown in Figure 2.

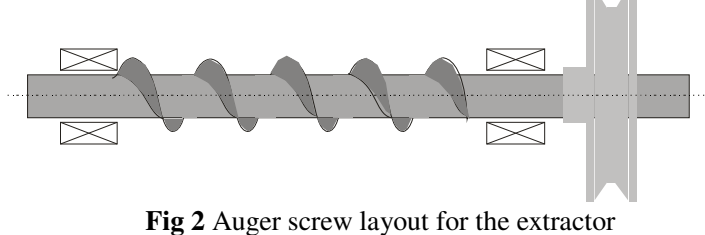

Fig 2 Auger screw layout for the extractor 
The requirement for the sizing of the shaft includes determining the locations of the bearing supports and the drive mechanism. The bearings are placed on either side of the drive mechanism for purpose of providing stable support for the shaft. The state of the stress considered is caused by the torque transmitted by the belt drive to the shaft including shaft bending due to its weight, load exerted on it by the hopper content, and the force exerted axially due to the squeezing operation of the tiger nuts against the end plate where the extraction takes place. The diameter of the shaft is obtained as expressed in equation (8).

$d_{o}^{3}=\frac{F S}{\sigma_{y}} \frac{32}{\pi} B\left\{\left[M+\frac{F d_{o}}{8}\left(1+\alpha^{2}\right)\right]^{2}+\frac{3}{4} T^{2}\right\}^{1 / 2}$

Where FS is the factor of safety for the design based on design judgment, $\sigma_{y}$ is the material yield strength, $\mathrm{M}$ is the bending moment due to the shaft loading, $\mathrm{T}$ is the torsion load on the shaft, $\mathrm{F}$ is the axial force on the screw, $\alpha$ is ratio $\frac{d_{i}}{d_{o}}$, where $\mathrm{d}_{\mathrm{i}}, \mathrm{d}_{\mathrm{o}}$ are the shaft internal diameter external diameter respectively. $\mathrm{B}$ is the hollowness factor and could be obtained as $B=$ $\frac{1}{1-\alpha^{4}}$

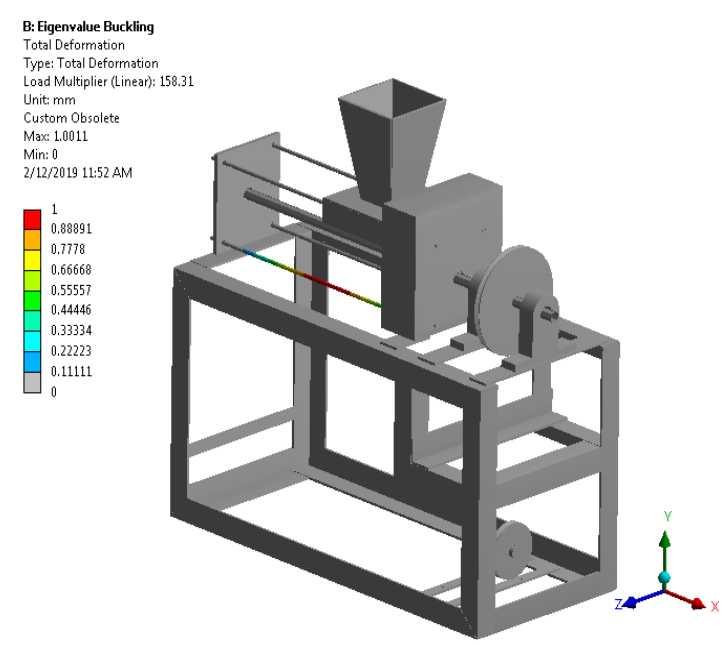

Fig 3 Tiger nut milk extractor machine skeletal frame

Frame structure: The frame of the machine is fabricated using 1.5 angle iron of mild steel. The manufacturing process involve include cutting, grinding, welding and the use of bolt and nuts where necessary for structural rigidity. The frame skeletal is as shown in Figure 3. The structural analysis of the machine is been investigated in another paper.

Fabrication of the juice extractor: Manufacturing processes such as cutting, bending, machining, welding, drilling, and grinding were employed for the fabrication of the frame. The machine was developed in subassemblies of the frame structure, the auger screw and the hopper and the perforated barrel. The hopper and barrel assembly is mounted on the machine frame by welding and bolting. The auger screw assembly is mounted by the bearing blocks. The complete assembly is shown in Figure 1.

\section{RESULTS AND DISCUSSION}

Design analysis: The design parameters for the machine include the quantity of the tiger nuts by weight, the electric motor designed power, the speed of the belt drive, the output speed of the auger shaft, and the quantity by volume of the juice extracted from the processed tiger nuts. The result from the design analysis is as shown in Table 3. The design shaft diameter is obtained as $47.6 \mathrm{~mm}$ considering a factor of safety of 2.0. The decision for a factor of safety of 2.0 is assuming the worst scenario of likely failure of the shaft during operation under steady loading condition. Standard shaft of $50 \mathrm{~mm}$ however was selected. A metric standard parallel keyway produced on the shaft is of width by height $14 \mathrm{~mm} \times 3.8 \mathrm{~mm}$ and the key size selected for the standard shaft diameter is $14 \mathrm{~mm} \times 9 \mathrm{~mm}$.

\begin{tabular}{lr}
\multicolumn{2}{c}{ Table 3 Results of design analysis } \\
\hline Parameters (Unit) & Values \\
\hline Volume of Hopper, $\mathrm{V}\left(\mathrm{cm}^{3}\right)$ & 2726 \\
Weight of Load (Tiger-nut), w $=\mathrm{Vg}(\mathrm{N})$ & 19.23 \\
V-belt section A71, Internal diameter, mm & 1800 \\
Pitch length of belt, $\mathrm{L}_{\mathrm{p}}(\mathrm{mm})$ & 1833 \\
Output Pulley diameter, $\mathrm{D}_{\mathrm{o}}(\mathrm{mm})$ & 212 \\
Input Pulley diameter $\mathrm{D}_{\mathrm{i}}(\mathrm{mm})$ & 125 \\
Center-to-center Pulley distance, $(\mathrm{mm})$ & 651 \\
Output Speed of belt drive $(\mathrm{rpm})$ & 295 \\
Belt-pulley lap angle, $\square \mathrm{i}(\mathrm{deg})$. & 172.33 \\
Belt Speed, $\mathrm{v}_{\mathrm{b}}(\mathrm{m} / \mathrm{s})$ & 3.273 \\
Design Power, $\mathrm{P}_{\mathrm{d}}(\mathrm{kW})$ & 1.551 \\
Design Power, $\mathrm{P}_{\mathrm{a}}(\mathrm{kW})$ & 1.5141 \\
& 600, \\
Tension Loading; $\left(\mathrm{T}_{1}, \mathrm{~T}_{2}\right), \mathrm{N}$ & 141 \\
& $47.6 /$ \\
Shaft Outer dia. $\mathrm{d}_{\mathrm{o}} / \mathrm{Selected}(\mathrm{mm})$ & 50 \\
Shaft Internal dia. $\mathrm{d}_{\mathrm{i}}(\mathrm{mm})$ & 28 \\
\hline
\end{tabular}

Performance evaluation: The technical evaluation of the machine was carried out using set of load values $1.5 \mathrm{~kg}, 2.0 \mathrm{~kg}, 2.5 \mathrm{~kg}, 3 \mathrm{~kg}$ and $5 \mathrm{~kg}$. These values were arbitrarily chosen to evaluate the machine below and above design load weight. Slipping of the belt against the pulley was observed during operation which is due to insufficient initial tension used for assembling the belt on the pulleys. Figure 4 shows the quantity of the tiger nut milk produced per kilogram of the material. The quantity of milk juice extracted from the tuber increases with increasing weight of the nuts to a certain level of about $2.5 \mathrm{~kg}$ for this machine after which the quantity of milk per weight of the nut reduces with increasing weight of the nuts. 


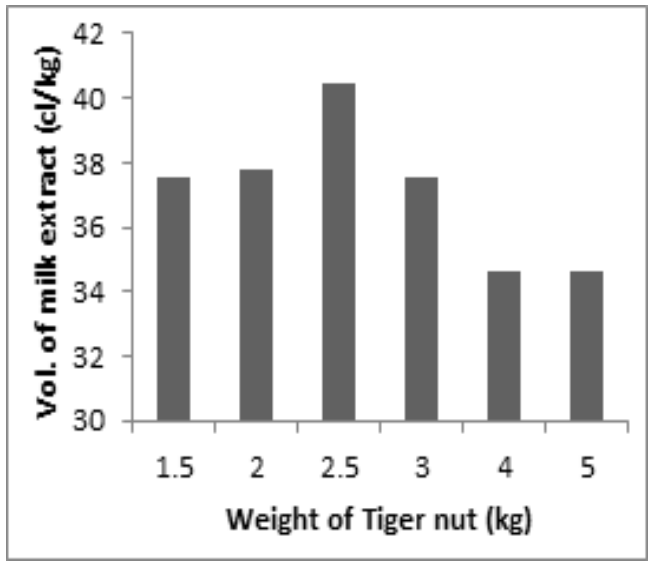

Fig 4 Quantity of Tiger nut milk per kilogram

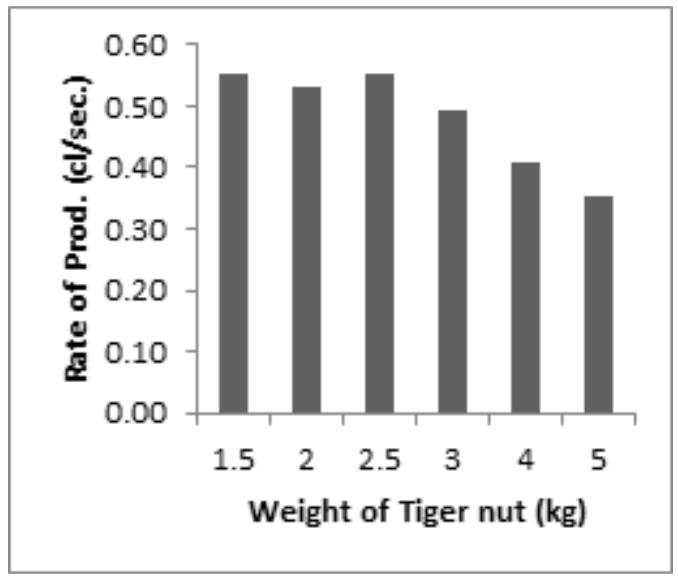

Fig 5 Rate of production of Tiger nut milk from Tiger nut tuber

A comparison with the plot of the rate of production in Figure 5 shows that the speed of operation of the pressing auger screw tends to reduce thereby requiring more time to do the extraction. This implied that the increase in quantity of the tiger nut tends to subjected the auger screw to such loading above the limit which the drive could accommodate thus slows down the system while requiring more energy for operation. It therefore could be inferred that although the machine is designed to accommodate $3 \mathrm{~kg}$ of tiger nut for processing, it should be recommended that the quantity of nuts that could be processed conveniently with the machine should be within the range $\leq 2.5 \mathrm{~kg}$.

Conclusion: The study proposes a suitable machine developed for extracting tiger nut juice with efficientenergy usage using locally sourced material for costeffectiveness. The machine is powered by a $2.0 \mathrm{hp}$ electric motor via a V-belt mechanism and designed to process $<3 \mathrm{~kg}$ of the tiger nut for small scale production. Performance evaluation of the machine shows that its efficiency is within the range of 53-55\% for a power requirement of $1.514 \mathrm{~kW}$ and could be developed for small scale food processing plant.

\section{REFERENCES}

Abou-Arab, AA; Mamoud, MH; Abu-Salem, FM (2017). Influences of Juice Extraction and Drying Methods on the Chemical Analysis of Lemon Peels. Inter. J. Nutr, Food Eng. 11(7): 584-589

Adanu, EO; Usman, DD; Maduako, JN (2015). Development and Performance Evaluation of an Orange Juice Extractor. Inter. J. Sci. Eng. Res. 6(3)

Adebayo, AA; Unuigbe, OM; Atanda, EO (2014). Fabrication and performance evaluation of a portable motorized pineapple juice extractor. Innov, Sys. Design. Eng.. 5(8): 22-29.

Adejuyitan, JA (2011). Tigernut processing: Its Food uses and Health benefits. Am. J. Food Tech. 6(3): 197-201. DOI: 10.3923/ajft.2011.197.201

Al-Shaikh, MN; Wahab, TAA; Kareem, SHA; Hamoudi, SR (2013). Protective effect of chufa tubers (Cyperus esculentus) on induction of sperm abnormalities in mice treated with lead acetate. Int. J. Drug Dev. Res. 5: 387-392.

Aviara, NA; Lawal, AA; Nyam, DS; Bamisaye, J (2013). Development and performance evaluation of a multi-fruit juice extractor. Global J. Eng. Des..Tech. 2(2): 16-21

Bamishaiye, EI; Bamishaiye, OM (2011). Tiger nut: As a plant, its derivatives and benefits. Afr. J. Food Agric. Nutr. Dev. 11(5): 5157-5170.

Chevallier, A (1996). The encyclopedia of medicinal plants. Dorling Kindersley Press, London.

Ekaluo, UB; Ikpeme, EV; Etta, SE; Ekpo, PB (2015). Effect of Aqueous Extract of Tigernut (Cyperus esculentus L.) on Sperm Parameters and Testosterone Level of Male Albino Rats. Asian J. Biotechnology. 7 (1): 39-45.

Eyeowa, AD; Adesina, BS; Diabana, PD; Tanimola, OA (2017). Design, fabrication and testing of a manual juice extractor for small scale applications. Curr. J. Appl. Sci. Tech. 22(5): 1-7

Mercado, FL; Aguinaldo, TG; Gavino, HF; Taylan, VT (2016). Medium-scale multi-juice extractor for food Processing. Proceedings of Academics 
World 51st International Conference, Bangkok, Thailand, 16th-17th November 2016.

Odewole, MM; Falua, KJ; Adebisi, SO; Abdullahi, KO (2018). Development and Performance Evaluation of a Manually-Operated Multipurpose Fruit Juice Extractor. FUOYE J. Eng. Tech. 3(1): 48-51.

Ogbonna, AC; Abuajah, CI; Utuk, RA (2013). Tigernut Milk: A Nutritious Under-Utilized Food Ingredient. Food Biology, 2(2):14-17

Ogunlade, I; Adeyemi, BA; Aluko, OG (2015). Chemical compositions, antioxidant capacity of tigernut (cyperus esculentus) and potential health benefits. Eur. Sci. J., SPECIAL/ edition: 217-224

Ogunsina, BS; Lucas, EB (2008). Development of a Manually Operated Cashew Juice Extractor. Agricultural Engineeering International. The CIGR Ejournal. Manuscript FP 07 037. Vol.X: 119

Oguwike, FN; Eluke, BC; Eze, RI; Asika, CM; Nwosu, PN; Nwafor, C; Onumonu, C (2017). The effects of Cyperus esculentus (Tiger nut) on Haematological and Biochemical Profile of Male Hypercholesteremic Subjects in Uli, Anambra State Nigeria. Greener J. Med. Sci. 7(4): 36-41
Omoregie, MJ; Francis-Akilaki, TI; Okojie, TO (2018). Design and Fabrication of a Juice Extractor. J. Appl. Sci. Environ. Manage. 22 (2): $207-212$.

Owusu, NR, Owusu, PB (2016). Tiger nuts: a healthier pseudo - nut of all nuts in the tropics. Int. J. Innov. Res. Multi. Field. 2(12): 307-312.

Raji, NA; Erameh, AA; Yussouff, AA; Durojaye, RO (2016) Response Surface Methodology Approach for Transmission Optimization of V-Belt Drive. Modern Mech. Eng. 6: 32-43.

Sánchez-Zapata, E; Fernández-López, J; PérezAlvarez, JA (2012). Tiger Nut (Cyperus esculentus) Commercialization: Health Aspects, Composition, Properties, and Food Applications. Comp. Rev. Food Sci. Food Safety, 11: 366-377 